\title{
POST DISMISSAL EARNING AND REDUCTION OF MONETARY COMPENSATION FOR UNFAIR DISMISSAL IN MALAYSIA
}

\author{
Ashgar Ali Ali Mohamed ${ }^{1 *}$, Mohd Akram Shair Mohamed ${ }^{2}$, \\ Farheen Baig Sardar Baig ${ }^{3}$ \\ ${ }^{1}$ Prof. Dr., International Islamic University Malaysia, Kuala Lumpur, Malaysia, ashgar@iium.edu.my \\ ${ }^{2}$ Prof. Dr., International Islamic University Malaysia, Kuala Lumpur, Malaysia akram@iium.edu.my \\ ${ }^{3}$ Assoc. Prof. Dr., International Islamic University Malaysia, Kuala Lumpur, Malaysia, \\ baigfarheen007@yahoo.com \\ ${ }^{*}$ Corresponding author
}

\begin{abstract}
At common law, a wrongfully dismissed workman is bound to make reasonable exertion and show diligence in endeavouring to procure alternative employment. Failure to accept suitable alternative employment or take reasonable steps to procure the same would result in a deduction from the total amount recoverable for unfair dismissal calculated on a sum representing the amount the workman might have earned during the period. If the workman is unable to secure a comparable job, or where a comparable job did not exist having regard to the nature of his responsibilities and skill requirement, rate of pay and the location, he is not bound to accept such employment nor will a reduction be warranted. The burden is on the employer to present credible evidence that it is more likely than not that the workman failed to mitigate the loss, and the court will consider the steps taken by the workman to mitigate the loss. In Malaysia, the Industrial Court is required to reduce or scale down the back wages when there was a post dismissal earning after the dismissal, a percentage of such earning shall be deducted from the back wages. The Court should take into account all relevant matters including the fact, where it exists, that the workman has been gainfully employed elsewhere after his dismissal. An employee who has not been gainfully employed since his dismissal, or who has been gainfully employed but on a woefully small salary, should clearly say so to the court. To remain silent is to risk the court making a deduction deemed reasonable by the court. Apart from the duty to mitigate loss, the quantum of deduction, the factors that need to be considered and the sum that the employee will finally receive is equally important to be discussed. In light of the above, this paper discusses the duty of the employee to mitigate the loss following an unfair dismissal and the quantum of deduction with reference to the practice in Malaysia and United Kingdom.
\end{abstract}

Keywords: Post Dismissal Earning, Monetary Compensation, Reduction of

\section{INTRODUCTION}

The monetary compensation for dismissal without just cause or excuse is subject to such reduction to such proportion as is just and equitable. Reduction may be possible in the following circumstances namely, when the employee contributed to the dismissal and when there was a post-dismissal earning after the dismissal. In relation to the latter, which form the focus of this paper, a dismissed employee who finds alternative 
employment is said to be 'mitigating' his losses. A dismissed employee is under a positive obligation to mitigate his or her loss following termination by taking reasonable steps to secure or making reasonable efforts to secure alternative employment. This would necessarily include registering with employment agencies, speaking to contacts, reading the jobs section in the newspapers, commencing self-employment, relocating to obtain a suitable job in the employee's particular field or even accepting a lesser position with same employer, among others. The dismissal employee however is not required to take a radically different job to meet his duty to mitigate. Where the employee secures a new position, there will be a consequent reduction in any compensation by such proportion as the court considers just and fair in all the circumstances. In the absence of any efforts to secure alternative employment, it is open to the court to reduce compensation payable to an amount that the court deems the employee would have obtained had he or she mitigated his or her losses.

In Dr James Alfred v Koperasi Serbaguna Sanyo Bhd (Sabah) \& Anor [2001] 3 CLJ 541, the Federal Court, the apex court in Malaysia, stated inter alia, that the Industrial Court should take into account all relevant matters including the fact, where it exist, that the workman has been gainfully employed elsewhere after his dismissal. When there is a post dismissal earning, a percentage of such earning, to be decided by the court shall be deducted from the back wages. Again, in DTS Trading Sdn Bhd v Wong Weng Kit [2008] 1 ILR 548, the Industrial Court noted that 'in a society such as ours where a person would invariably have to work in order to sustain day to day living, the court is of the view that even if no evidence is adduced as regards to post dismissal earnings, the court is entitled nevertheless to make a deduction for post dismissal earnings. As such, a claimant who has not been gainfully employed since his dismissal, or who has been gainfully employed but on a woefully small salary, should clearly say so to the court. To remain silent is to risk the court making a deduction deemed reasonable by the court.'

Besides the duty to mitigate loss, the quantum of deduction and the sum that the employee will finally receive is equally an important issue that requires determination. It is appropriate to determine the factors that the court would consider for appropriate apportionment from the employee's monetary compensation for mitigate of loss. In light of the above, this paper discusses the employee's duty to mitigate loss following the alleged unfair dismissal and the quantum of deduction with special reference to the law and practice in Malaysia. Reference will also be had to the position in the United Kingdom.

\section{EMPLOYEE'S DUTY TO MITIGATE LOSS AT COMMON LAW}

At common law, a worker whose contract of employment has been wrongfully terminated is bound to make reasonable exertion and show diligence in endeavouring to procure alternative employment. Any amount received from the substituted employment would be taken into account to reduce the damages. All that the worker is required to do is to take reasonable steps obtain reasonable alternative employment. The reasonableness of such alternative employment is based on the geographical location, the nature of the work, including the pay, status and responsibility, and the workers' personal status in life. In Bohemier $v$ Strowal International Inc (1982) 142 DLR (3d) 8, a Canadian case, the employee, who responded to an advertisement published by the manpower office, was regarded as having attempted to mitigate his loss.

However, the employee is not required to take all possible steps to mitigate the loss. For example, he does not have to travel across the whole country, probably at his own expense, simply to lessen the damages to which he would otherwise be entitled or even accept employment at a lower rate of pay or status. It was further noted that the worker was not under any obligation to take a significant demotion in a new job as compared to his former job, or accept a lower salary or by go back to the employer who fired him. Steps such as searching for another job or even undertaking training to learn new technology would be considered as sufficient (See Ross v Pender [1974] 1 R 352).

Failure to accept suitable alternative employment or take reasonable steps to procure the same would result in a deduction from the total amount recoverable calculated on a sum representing the amount the employee might have earned during the period. It is for the employer to establish on the balance of probabilities that the aggrieved worker failed to mitigate damage (See Edward $v$ Society of Graphical and Allied Trades [1971] Ch 354, [1970] 3 All ER 689, CA (Eng); London and South of England Building Society $v$ Stone [1983] 1 WLR 1242, 1262, CA (Eng); Red Deer College v Michaels (1975) 57 DLR (3d) 386, 391). In Brace v Calder \& Ors [1895] 2 QB 253, CA (Eng), an English case, the defendants were a partnership consisting of four members. The plaintiff was employed as manager of a branch of their business for a certain period. Before the period expired, two of the partners retired and the business was transferred to, and carried on by, the other two partners. The continuing partners were willing to employ the plaintiff on the same terms as before for the remainder of the period but he declined to serve them. The court held that dissolution of partnership operated as a wrongful dismissal and since the plaintiff failed to mitigate damage by accepting the employment, the plaintiff was entitled only to nominal damages. Again, in Stocks $v$ Magna Merchants Ltd 
[1973] 2 All ER 329, an English case, Arnold J. stated: 'the proper measure of damages for wrongful dismissal is the amount of the loss suffered by the plaintiff and that this falls to be determined by taking the gross amount of the remuneration which the plaintiff would have earned during the remainder of his period of service less any amount which he has or ought to have earned elsewhere, and by deducting therefrom the diminution which the gross would have suffered if he had, in fact, earned it'.

\section{EMPLOYEE'S DUTY TO MITIGATE LOSS PURSUANT TO IRA}

In the sphere of the Industrial Relations Act 1967 (IRA), an unjustly dismissed employee is under a duty to mitigate loss by using reasonable effort to secure and obtain gainful employment while his case is pending in the Industrial Curt. The actual earning during this period enables the court to set off against any compensation otherwise recoverable. Before the Federal Court, in Dr James Alfred (Sabah) v Koperasi Serbaguna Sanya Bhd (Sabah) and Anor [2001] 3 CLJ 541, set its views on the duty of the claimant to mitigate loss by seeking gainful employment, the Industrial Court was divided as to application of the employee's common law duty to mitigate loss in the industrial jurisprudence.

In some cases, the Court held that a workman ought to mitigate his loss by seeking alternative employment in the interim period (Syarikat Eastern Smelting Bhd v Kesatuan Kebangsaan Pekerja-pekerja Perusahaan Pelaboran Logam Sa-Malaya (Award No 19 of 1968) and Transport Workers' Union v Selangor Omnibus Co Ltd [1981] MLLR 179). While in other cases, the Court held otherwise (Boots Co (Far East) Pte Bhd, Singapore $v$ Kenneth Toh Lee Soon Teong [1981] MLLR 681). C.P.Mill, a prominent labour scholar, favoured the latter approach where he stated: 'the principle of mitigation of damages can have no logical place in a jurisdiction which is concerned primarily with reinstatement issues. This is so because "in reinstatement proceedings the man is claiming that, according to the principles of the Industrial Court, his dismissal was wrongful and that he is entitled to an order that will compel the employer to recognize the contract as still on foot and binding on both parties.'

In Thilagavathy a/l AlaganMuthiah v Meng Sing Glass Sdn Bhd [1997] 3 MLJ 735, Abdul Kadir Sulaiman J held that: 'it is inconsistent for a workman to seek reinstatement on the one hand and be required to seek employment elsewhere by way of mitigation on the other. To require him to seek employment elsewhere while the claim is pending would be tantamount to his abandoning his claim for reinstatement.' It is noteworthy that section 20(1) of the Industrial Relations Act 1967 requires the dismissed workman to make his representation in writing, which must be filed at the office of the Director General nearest to the place of employment from which the workman was dismissed. In his representation, he must seek to be reinstated into the position held immediately before the dismissal. Haidar Mohd Noor J, in Holiday Inn, Kuching $v$ Lee Chai Siok Elizabeth [1992] 1 MLJ 230, stated: 'The legislature intended that recourse to the Industrial Court is only in respect of reinstatement and once reinstatement is no longer applied for, the Industrial Court ceases to have any more jurisdiction'.

Reverting to Thilagavathy's case, Abdul Kadir Sulaiman $\mathrm{J}$ further stated: 'a workman who is forced by the mitigation principle to seek employment elsewhere may find himself in an awkward position when the Industrial Court orders reinstatement to his former position. He will be in a dilemma. If he does not report back to work with his former employer as ordered by the court, he may be deemed to have abandoned his job. He may be liable to the former employer for wages in lieu of notice. Conversely, if he leaves his employment and returns to his reinstated position, he will be held liable to his new employer for wages in lieu of notice. In either way, the imposition of mitigation principle impairs industrial harmony and induces breach of contract of employment. A court of equity and good conscience cannot afford to own this principle at the expense of industrial harmony.' His lordship further added that the claimant seeks employment during the interim period: 'out of sheer necessity to maintain himself and those depending on him for a livelihood. It is inequitable to require him to off-set that amount which he earned in order to survive.'

The duty of the employee to mitigate loss was finally resolved by the Federal Court in Dr James Alfred, Sabah v Koperasi Serbaguna Sanya Bhd, Sabah \& Anor [2000] 4 MLJ 87 CA. The appellant in this case, a general manager in the respondent company, was dismissed from employment on the grounds of misconduct for allegedly abusing his authority. The Industrial Court found in favour of the appellant and awarded him monetary compensation in lieu of reinstatement. Subsequently, the respondent applied to the High Court to quash the award, but this was rejected, so they appealed to the Court of Appeal. The appeal was dismissed except for the award of back wages. The appellant then filed leave to the Federal Court, which was granted on the question of law, namely, whether the Industrial Court was bound to deduct or set off from back wages, wages and remuneration earned elsewhere by the appellant from the date of dismissal to the date of the award.

The Court answered in the affirmative by holding that the: 'Industrial Court, in assessing quantum of back 
wages, should take into account the fact, if established by evidence or admitted, that the workman has been gainfully employed elsewhere after his dismissal. Failure to do so constitutes a jurisdictional error of law. Certiorari will therefore lie to rectify it.' The Federal Court further added that: 'taking into account of such employment after dismissal does not necessarily mean that the Industrial Court has to conduct a mathematical exercise in deduction. What is important is that the Industrial Court, in the exercise of its discretion in assessing the quantum of back wages, should take into account all relevant matters including the fact, where it exists, that the workman has been gainfully employed elsewhere after his dismissal.'

In light of the Federal Court's decision in Dr James Alfred's case, the Industrial Court is require to take into consideration the amount received from other employment during the interim period which will be deducted, in considering the calculation of the back wages. The above is now reflected in the second schedule to the Industrial Relations Act 1967. In particular, section 30(6A) requires the Industrial Court to take into account the factors set out in the second schedule: (i) In the event that back wages are to be given, such back wages shall not exceed twenty four months back wages from the date of dismissal based on the last drawn salary of the person who has been dismissed without just cause or excuse. (ii) Where there is post-dismissal earnings, a percentage of such earnings, to be decided by the Court, shall be deducted from the back wages given.

As from the above, the rule on mitigation of loss is now applicable in the sphere of industrial jurisprudence. The learned Chairman of the Industrial Court, Mr. Lim Heng Seng, in Nestle Food Storage (Sabah) Sdn Bhd $v$ Terrence Tan Nyang Yin [2002] 1 ILR 280, noted that the duty of mitigation of loss has the "basis in equity, good conscience and certainly in justice and common sense". Its objective is primarily to ensure that the claimant does not take double advantage and make excessive gains relying on the wrongful act of the employers. The learned Chairman further added: 'It cannot be just and equitable; it certainly offends good conscience, common sense and simple logic, that the indolent workman or the different employee who can afford not to work but prefer to remain unemployed or does not exert himself sufficiently to get employment elsewhere is awarded back wages in full while the conscientious claimant who had diligently sought alternative employment is not awarded back wages at all or has the award reduced by the earnings he had received from his gainful employment elsewhere.'

In light of the above observation, the common law principle that a wrongfully dismissed workman is bound to make reasonable exertion and show diligence in endeavouring to procure alternative employment applies in the sphere of industrial jurisprudence in Malaysia. As stated earlier, failure to accept suitable alternative employment or take reasonable steps to procure the same would result in a deduction from the total amount recoverable calculated on a sum representing the amount the workman might have earned during the period. In Crest Ultrasonics (Malaysia) Sdn Bhd v Liew Siew Kim [2003] 1 ILR 565, the Industrial Court deducted $35 \%$ of the back wages which the claimant was entitled because the claimant did not make any effort to find employment despite her qualifications.

However, if the workman is unable to secure a comparable job, or where a comparable job did not exist having regard to the nature of his responsibilities and skill requirement, rate of pay and the location, he is not bound to accept such employment nor will a reduction be warranted. The burden of proving is on the employer to present credible evidence that it is more likely than not that the workman failed to mitigate the loss, and the court will consider the steps taken by the workman to mitigate the loss.

It is worth noting that in Brake $v$ PJ-M2R Restaurant Inc. (2016) ONSC 1795, the Canadian Court acknowledged that the claimant's new job found post-termination was "so substantially inferior" to the position she had previously held and that it did not help her in terms of mitigating her losses post termination. In this case, the plaintiff had worked at the employer for over 25 years. She had little formal education and had been promoted through the ranks to a management position. Her claim for constructive dismissal was upheld by the court. In relation to mitigation of loss, she had made efforts to mitigate her damages, including working at another company that offered her less perks, and attempting to start a babysitting business and a cleaning service. At no point was she able to secure a management position similar or equivalent to the one she had held at the company. Justice Phillips stated:

"At the time she was constructively dismissed, Esther Brake was 62 years old (she is now 65). She had worked for McDonald's in some capacity for the majority of her working life. She had effectively worked for the Defendant for 20 of those years. She has little in the way of formal education. She rose to a management position through perseverance and hard work. Her knowledge and skills are mostly applicable to only the McDonald's environment, a work place that very much has its own unique culture, language and ways of doing things. Since her dismissal, despite her reasonable best efforts, she has not managed to secure a reasonably comparable managerial position. I find that her subsequent employment represents a reasonable effort on her part to mitigate her losses. However, I also find that her ability to find employment 
does not take away from the loss she suffered from being dismissed without cause. The cashier position she occupies now at Home Depot is so substantially inferior to the managerial position she held with the Defendant that the former does not diminish the loss of the latter."

\section{QUANTUM OF DEDUCTION}

Apart from the duty of the employee to mitigate his loss by seeking alternative employment in the interim period, the issue arises on the quantum of deduction and the sum that the employee will finally receive. In $D r$ James Alfred's case, the Federal Court stated: 'taking into account of such other employment after dismissal does not necessarily mean that the Industrial Court has to conduct a mathematical exercise in deduction.' In Malayan Banking Berhad v Mahkamah Perusahaan Malaysia \& Anor [2016] MLJU 919, the High Court noted that there is no mathematical formula for the rescaling exercise prescribed both in $\operatorname{Dr}$ James Alfred's case as well as in the Second Schedule to the Industrial Relations Act 1967. Thus, it is left to the discretion of the presiding tribunal to determine the quantum to be taken into account. Such discretion was held to be in the nature of a decision making process and therefore subject to correction upon judicial review.

In Malayan Banking Berhad's case, the issue before the High Court was whether the first respondent was correct in only rescaling $20 \%$ from the backwages in light of proof of post dismissal earnings. In relation to this issue, the court stated inter alia, that since there was evidence that the post dismissal earning of the second respondent was almost three times her salary before she was dismissed albeit only after a period of about eight (8) months, the first respondent ought to have adopted a more liberal figure for rescaling. Under all the circumstances, the court was of the opinion that a rescaling of $40 \%$ would have been more appropriate.

However, in some cases for example in Healthcare Medical Screening Centre (M) Sdn Bhd v Kogilavani Muniandy [2002] 1 ILR 448, the Industrial Court had resorted to arithmetical calculation in the deduction. In Kogilavani Muniandy's case, the claimant, an assistant manager, alleged that her termination due to business loss was a collateral exercise as the company had advertised for additional staff offering a higher salary after her departure. The trial was conducted ex-parte because the company did not enter appearance on the date of the hearing. The Court found in favour of the claimant and awarded monetary compensation. A sum of RM44, 936 was awarded which represents an award of back wages and compensation in lieu of reinstatement. A sum of RM25, 730 was deducted from the above sum which represents the amount she had earned from alternative employment during the interim period. This means that the claimant was only entitled to RM19, 206 using the mathematical formula of deduction which is, compensation awarded by the Court minus the total sum earned from the new employment.

Again, in Artworld Advertising Sdn Bhd v Nor Azian Bt Mohd Salleh \& Anor [2004] 7 MLJ 349, the Industrial Court awarded the first respondent a sum of RM43,200 as backwages. However, no deduction was made from the above sum by way of mitigation of loss although the evidence established shows that the first respondent was gainfully employed elsewhere with a salary of RM600 per month, four months after her termination. Before the High Court it was submitted for the appellant that deduction should be made on the backwages awarded to the first respondent and failure by the Industrial Court to do so empowered this court to set aside the award. The court agreed and accordingly made an order that RM600 per month for 20 consecutive months be deducted from the award in respect of the back wages.

It is submits that if the formula used in Kogilavani Muniandy and Nor Azian Bt Mohd Salleh's case is followed as a guide, it would be unfair to the claimant who might end up with minimum sum or nothing at all if soon after the dismissal he secured employment that offers same or better remuneration. Although this may be the case, in a large number of cases, the courts have used their own discretion in arriving at the deduction of only a certain percentage instead of resorting to the mathematical calculation.

The table below further illustrates with reference to the awards of the Industrial Court involving the reduction of back wages arising from the rule on mitigation of loss. 
TABLE: MONETARY AWARD OF INDUSTRIAL COURT FOR UNFAIR DISMISSAL: MITIGATION OF LOSS

\begin{tabular}{|c|c|c|c|c|}
\hline No. & Case & $\begin{array}{l}\text { Amount of back } \\
\text { wages awarded }\end{array}$ & Mitigation of Loss & Justification for the reduction \\
\hline 1. & $\begin{array}{l}\text { Elbis Shuhaimi Zakaria } \\
\text { v PECD } \\
\text { Berhad/Peremba } \\
\text { Construction Sdn Bhd } \\
\text { [2011] } 2 \text { LNS } 0726\end{array}$ & RM210,480.00 & $\begin{array}{l}\text { Deduction of } 15 \% \text { from } \\
\text { the backwages }\end{array}$ & $\begin{array}{l}\text { The claimant was unemployed since his dismissal and he only managed } \\
\text { to secure new employment about a year later with higher salary than his } \\
\text { last drawn salary with the Company. }\end{array}$ \\
\hline 2. & $\begin{array}{l}\text { Abd Manap Kamal } \\
\text { Baharin v Bumiputra } \\
\text { Commerce Finance } \\
\text { Bhd [2010] } 2 \text { LNS } \\
0874\end{array}$ & RM78,528.00 & $\begin{array}{l}\text { Deduction of } 5 \% \text { from the } \\
\text { backwages }\end{array}$ & No reasons given for the $5 \%$ deduction for the post dismissal earnings. \\
\hline 3. & $\begin{array}{l}\text { Wan Rusmina Othman } \\
\text { \& Anor v AiNB Tech } \\
\text { (M) Sdn Bhd [2009] } 2 \\
\text { LNS } 1294\end{array}$ & $\begin{array}{l}\text { A sum of } \\
\text { RM72,500.00 was } \\
\text { awarded to the } 1^{\text {st }} \\
\text { claimant and } \\
\text { RM40,000.00 to the } \\
2^{\text {nd }} \text { claimant }\end{array}$ & No deduction made & $\begin{array}{l}\text { While Dr. James Alfred's case was cited and further the court } \\
\text { acknowledged that the claimants had some source of income since the } \\
\text { termination of their employment, nevertheless no deduction was made by } \\
\text { way of mitigation of loss. }\end{array}$ \\
\hline 4. & $\begin{array}{l}\text { Mohd Tarmizi Aksah v } \\
\text { Bank Kerjasama } \\
\text { Rakyat Malaysia } \\
\text { Berhad [2013] } 2 \text { LNS } \\
1842\end{array}$ & RM246,312.00 & $\begin{array}{l}\text { Deduction of } 40 \% \text { from } \\
\text { the backwages }\end{array}$ & $\begin{array}{l}\text { There was a mere mention of the } 40 \% \text { deduction of the backwages due to } \\
\text { the claimant's post-dismissal earnings and the fact that the claimant did } \\
\text { contribute to the company acting in the manner they did against the } \\
\text { claimant. }\end{array}$ \\
\hline 5. & $\begin{array}{l}\text { Pilecon Geotechnics } \\
\text { Sdn Bhd \& Anor v } \\
\text { Phang Soon Ping } \\
\text { [2013] } 2 \text { LNS } 1212\end{array}$ & RM205,344.00 & $\begin{array}{l}\text { Deduction of } 20 \% \text { from } \\
\text { the backwages }\end{array}$ & $\begin{array}{l}\text { The Industrial Court stated inter alia, that with his years of working } \\
\text { experience, had he acted reasonably he would have secured gainful } \\
\text { employment and earned a reasonable income after his dismissal. }\end{array}$ \\
\hline 6. & $\begin{array}{l}\text { Ali Long v Focus Park } \\
\text { Sdn Bhd [2013] } 2 \text { LNS } \\
1098\end{array}$ & RM96,000.00 & $\begin{array}{l}\text { Deduction of } 20 \% \text { from } \\
\text { the backwages }\end{array}$ & $\begin{array}{l}\text { The Court took into account the fact that after his dismissal, the Claimant } \\
\text { was involved in selling "nasi lemak" and earned about RM700.00- } \\
\text { RM800.00 per month. }\end{array}$ \\
\hline 7. & $\begin{array}{l}\text { Othman Haron \& Ors } v \\
\text { Park Avenue Sungai } \\
\text { Petani [2013] } 2 \text { LNS } \\
0444\end{array}$ & $\begin{array}{l}\text { A sum of } \\
\text { RM } 180,000.00 \text { was } \\
\text { awarded to the } 2^{\text {nd }} \\
\text { Claimant and } \\
\text { RM } 45,600.00 \text { to the } \\
3^{\text {rd }} \text { claimant }\end{array}$ & $\begin{array}{l}\text { Deduction of } 30 \% \text { were } \\
\text { made from the } \\
\text { backwages awarded to } \\
2^{\text {nd }} \text { claimant }\end{array}$ & $\begin{array}{l}\text { There was evidence to show that after the } 2^{\text {nd }} \text { claimant's dismissal he was } \\
\text { gainfully employed thereafter. }\end{array}$ \\
\hline 8. & $\begin{array}{l}\text { Khew Chee Sun v HSL } \\
\text { Electrical \& Electronics } \\
\text { Sdn Bhd [2013] } 2 \text { ILJ } \\
\text { 50, [2012] } 2 \text { LNS } 1671\end{array}$ & RM168,000.00 & $\begin{array}{l}\text { Deduction of } 10 \% \text { from } \\
\text { the backwages }\end{array}$ & $\begin{array}{l}\text { The deductions for post-dismissal earnings was made as the claimant had } \\
\text { testified that he had earned about RM6,000.00 from } 2 \text { projects. }\end{array}$ \\
\hline 9. & $\begin{array}{l}\text { Teh Khye Chin v Build } \\
\text { Horse (M) Sdn Bhd }\end{array}$ & RM408,000.00 & $\begin{array}{l}\text { Deduction of } 20 \% \text { from } \\
\text { the back wages }\end{array}$ & $\begin{array}{l}\text { There was evidence that the claimant was gainfully employed after he } \\
\text { was dismissed from the company. }\end{array}$ \\
\hline
\end{tabular}




\begin{tabular}{|c|c|c|c|c|}
\hline & [2012] 2 LNS 1033 & & & \\
\hline 10. & $\begin{array}{l}\text { Shariza Mohd Shaari \& } \\
\text { Anor v Oriental Capital } \\
\text { Assurance Berhad } \\
\text { [2012] } 2 \text { LNS } 0258\end{array}$ & $\begin{array}{l}\text { A sum of } \\
\text { RM42,933.00 and } \\
\text { RM54,648.00 was } \\
\text { awarded to the } 1^{\text {st }} \\
\text { and } 2^{\text {nd }} \text { claimants. }\end{array}$ & $\begin{array}{l}\text { Deduction of } 30 \% \text { from } \\
\text { the backwages }\end{array}$ & $\begin{array}{l}\text { Both the claimants have been employed with a higher salary few months } \\
\text { after their dismissal. }\end{array}$ \\
\hline 11. & $\begin{array}{l}\text { Koh Guan Swee v } \\
\text { Metroplex Berhad \& } \\
\text { Anor [2013] } 2 \text { LNS } \\
1760\end{array}$ & RM60,000.00 & $\begin{array}{l}\text { Deduction of } 50 \% \text { from } \\
\text { the backwages }\end{array}$ & $\begin{array}{l}\text { In this case, there was no evidence put forward by the claimant to show } \\
\text { whether he was gainfully employed or otherwise after the termination. The } \\
\text { Industrial Court noted that based on the claimant's qualification and } \\
\text { background it was most unlikely that he was not able to secure an } \\
\text { employment elsewhere. Hence, in exercising the discretion in equity, good } \\
\text { conscience and substantial merit of the case the court reduced the } \\
\text { backwages award by } 50 \% \text {. }\end{array}$ \\
\hline 12. & $\begin{array}{l}\text { Alvin Diraviam Bonjour } \\
\text { V Ecatec Services (M) } \\
\text { Sdn Bhd [2013] } 4 \text { ILJ } \\
411,[2013] 2 \text { LNS } 1501\end{array}$ & RM19,200 & $\begin{array}{l}\text { Deduction of } 20 \% \text { from } \\
\text { the backwages }\end{array}$ & $\begin{array}{l}\text { The claimant stated that he was gainfully employed one year after his } \\
\text { dismissal by the respondent. }\end{array}$ \\
\hline 13. & $\begin{array}{l}\text { Zamri Muda v Tenaga } \\
\text { Nasional Berhad [2013] } \\
2 \text { LNS } 1366\end{array}$ & RM12,018 & $\begin{array}{l}\text { Deduction of } 20 \% \text { from } \\
\text { the backwages }\end{array}$ & $\begin{array}{l}\text { Since the claimant found employment within six months after the date } \\
\text { of dismissal, } 20 \% \text { from the backwages was deducted for post } \\
\text { dismissal earning. }\end{array}$ \\
\hline 14. & $\begin{array}{l}\text { Sri Balan Ciwalingam v } \\
\text { Tamco Corporate } \\
\text { Holdings Bhd [2013] } 2 \\
\text { LNS } 1178\end{array}$ & RM35,088 & $\begin{array}{l}\text { Deduction of } 20 \% \text { from } \\
\text { the backwages }\end{array}$ & $\begin{array}{l}\text { There was evidence that the claimant was gainfully employed after he } \\
\text { was dismissed from employment from the company. }\end{array}$ \\
\hline 15. & $\begin{array}{l}\text { Yap Swee Kim v CYC } \\
\text { Hotels Sdn Bhd [2013] } \\
2 \text { LNS } 1055\end{array}$ & RM108,478.32 & No deduction made & $\begin{array}{l}\text { The Industrial Court stated inter alia, that since the claimant was } \\
\text { unemployed and in the absence of any post dismissal employment, no } \\
\text { deduction shall be made from the calculation of backwages. }\end{array}$ \\
\hline 16. & $\begin{array}{l}\text { Loke Pang Keong v } \\
\text { Subang Perdana } \\
\text { Services Sdn Bhd } \\
\text { [2013] } 2 \text { LNS } 0331\end{array}$ & RM136,000.00 & $\begin{array}{l}\text { Deduction of } 5 \% \text { from the } \\
\text { backwages }\end{array}$ & $\begin{array}{l}\text { As there was evidence of post dismissal earnings, albeit at lower salary, a } \\
\text { deduction of } 5 \% \text { from the backwages was considered reasonable. }\end{array}$ \\
\hline 17. & $\begin{array}{l}\text { Tan Yeok Wah v } \\
\text { Ayamas Food } \\
\text { Corporation Sdn Bhd } \\
\text { [2013] } 2 \text { LNS } 0165\end{array}$ & RM84,000.00 & No deduction made & $\begin{array}{l}\text { The claimant stated that she had not been able to find a permanent job } \\
\text { since her dismissal due to her age ( } 50 \text { on the date of dismissal) but she } \\
\text { had held temporary jobs. As the company did not bring in any evidence of } \\
\text { the claimant's post dismissal earnings, no deduction was ordered. }\end{array}$ \\
\hline 18. & $\begin{array}{l}\text { Hasdie Tusin v Kudat } \\
\text { Golf \& Marina Resort } \\
\text { (Tangamahir Sdn Bhd) } \\
{[2016] 2 \text { LNS } 1133}\end{array}$ & RM13,600.00 & $\begin{array}{l}\text { Deduction of } 30 \% \text { from } \\
\text { the backwages }\end{array}$ & $\begin{array}{l}\text { There was evidence adduced before the court that the claimant was } \\
\text { gainfully employed albeit on a part time basis earning about RM } 600.00 \\
\text { per month after he was dismissed by the Company. Hence, the court } \\
\text { made a deduction of RM } 30 \% \text { under this head. }\end{array}$ \\
\hline 19. & $\begin{array}{l}\text { Theivarani Muniandy v } \\
\text { Nadin Management } \\
\text { Sdn Bhd [2016] } 4 \text { ILR } \\
189\end{array}$ & RM660,000. & $\begin{array}{l}\text { Deduction of } 30 \% \text { from } \\
\text { the backwages }\end{array}$ & $\begin{array}{l}\text { The court orders a deduction of } 30 \% \text { from the backwages as there was } \\
\text { proof of the claimant's post dismissal earnings in the restaurants' } \\
\text { business. }\end{array}$ \\
\hline 20. & Lee Kee Meng $v$ & RM77,400.00 & Deduction of $30 \%$ from & The claimant was gainfully employed one and a half month after dismissal \\
\hline
\end{tabular}




\begin{tabular}{|c|c|c|c|c|}
\hline & $\begin{array}{l}\text { Comcolor Graphics Sdn } \\
\text { Bhd \& Ors [2016] } 4 \text { ILR } \\
45\end{array}$ & & the backwages & $\begin{array}{l}\text { with the salary of RM6,000 per month and travelling allowance of } \\
\mathrm{RM} 1,000 \text { per month. This was much higher than the claimant's last drawn } \\
\text { salary with the company. Hence, the court was of the opinion that scaling } \\
\text { down } 30 \% \text { of backwages was appropriate. }\end{array}$ \\
\hline 21. & $\begin{array}{l}\text { Mark Naqiudean Chan } \\
\text { Abdullah v Viewit } \\
\text { Malaysia Sdn Bhd } \\
\text { [2016] } 2 \text { LNS } 0813 \\
\end{array}$ & RM76,000.00 & $\begin{array}{l}\text { Deduction of } 25 \% \text { from } \\
\text { the backwages }\end{array}$ & $\begin{array}{l}\text { The claimant testified that he was unemployed for about } 3 \text { months and } \\
\text { found employment with a Company earning RM9,500.00 a month. } \\
\text { Nevertheless, the Court deems it appropriate to make a deduction of } 25 \% \\
\text { from the backwages. }\end{array}$ \\
\hline 22. & $\begin{array}{l}\text { Lee Seong Fatt Lwn. } \\
\text { Joint Management } \\
\text { Body Of Pearl Point } \\
\text { Condominium [2016] } 2 \\
\text { LNS } 0704\end{array}$ & RM45,000.00 & $\begin{array}{l}\text { Deduction of } 30 \% \text { from } \\
\text { the back wages }\end{array}$ & $\begin{array}{l}\text { The court was of the opinion that scaling down } 30 \% \text { of backwages was } \\
\text { appropriate. }\end{array}$ \\
\hline 23. & $\begin{array}{l}\text { Mohd Nor Haris v MISC } \\
\text { Berhad [2016] } 3 \text { ILR } 71\end{array}$ & RM128,640 & $\begin{array}{l}\text { Deduction of } 30 \% \text { from } \\
\text { the backwages }\end{array}$ & $\begin{array}{l}\text { The court was of the view that the backwages should be reduced by } 30 \% \\
\text { to account for his post dismissal earnings amongst other things. The } \\
\text { claimant had successfully secured employment and continues to be } \\
\text { employed. }\end{array}$ \\
\hline 24. & $\begin{array}{l}\text { Jamaluddin Sayuti v } \\
\text { Preston Shipyard Sdn } \\
\text { Bhd [2016] } 2 \text { LNS } 0460\end{array}$ & RM168,000.00 & No deduction made & $\begin{array}{l}\text { On the facts of this case, there was no evidence adduced before the } \\
\text { Court that he was in gainful employment after he was dismissed by the } \\
\text { Company. }\end{array}$ \\
\hline 25. & $\begin{array}{l}\text { Lechymy Supramaniam } \\
\text { v Dhl Global } \\
\text { Forwarding (M) Sdn } \\
\text { Bhd [2015] } 2 \text { LNS } \\
1142\end{array}$ & RM72,765.00 & $\begin{array}{l}\text { Deduction of } 20 \% \text { from } \\
\text { the backwages }\end{array}$ & $\begin{array}{l}\text { Taking into consideration that the claimant was gainfully employed } 3 \\
\text { months after her dismissal, the Court decided that it would be fair for the } \\
\text { Company to pay the claimant backwages on her last drawn monthly } \\
\text { salary of RM3,675.00 as follows: (a) for the period she was unemployed: } \\
3 \text { months } \times \text { RM3 } 3,675.00=\text { RM11,025.00; (b) for the period she was } \\
\text { gainfully employed } 21 \text { months } \times \text { RM3,675.00 - } 20 \% \text { of backwages = } \\
\text { RM61,740.00. }\end{array}$ \\
\hline 26. & $\begin{array}{l}\text { Foo Ah Long } v \\
\text { Maphilindo } \\
\text { International Sdn Bhd } \\
\text { [2015] } 2 \text { LNS } 0941 \\
\end{array}$ & RM79,044.00 & $\begin{array}{l}\text { Deduction of } 30 \% \text { from } \\
\text { the backwages }\end{array}$ & $\begin{array}{l}\text { The court was of the opinion that the backwages should be reduced by } \\
30 \% \text { to account for his post dismissal earnings amongst other things. The } \\
\text { claimant has successfully secured employment and continues to be } \\
\text { employed. }\end{array}$ \\
\hline 27. & $\begin{array}{l}\text { Chong Yeng Tau \& } \\
\text { Anor v Kim How } \\
\text { Jewellery (M) Sdn Bhd } \\
\text { [2015] } 2 \text { LNS } 0928\end{array}$ & RM36,960.00 & $\begin{array}{l}\text { Deduction of } 20 \% \text { from } \\
\text { the backwages }\end{array}$ & $\begin{array}{l}\text { The } 2^{\text {nd }} \text { Claimant had gainfully employed after her dismissal, therefore a } \\
\text { deduction of } 30 \% \text { shall be made from the calculation of backwages. }\end{array}$ \\
\hline
\end{tabular}


What is apparent from the above table is that the deduction from the claimant's back wages for the post dismissal earning is a speculative process and very much depended on the discretion of the Industrial Court chairman. So long as the court exercised its power in scaling down the backwages judiciously, the exercise of discretion will not be subject to review by the superior courts. In Beli Anak Empoi \& 2 Ors $v$ Sarku Engineering Services Sdn Bhd (Civil Appeal No. Q-02-2529-10/2011), the Industrial Court awarded the appellants 24 months' backwages with a deduction of $20 \%$ for post-dismissal earnings. The High Court affirmed the Industrial Court's award for dismissal without just cause in excuse, but reduced the award of backwages on the basis of the length of service. The Court of Appeal however set aside the decision of the High Court and restored the award of the Industrial Court. The Court stated that the Industrial Court had already taken into account the relevant mitigating circumstances when it reduced the 24 months backwages. Hence, there was no basis to disturb the finding of the Industrial Court.

Be that as it may, the use of discretionary power by the Industrial Court is measured according to the conscience of the Chairman of the Court. This is so because the Industrial Court is a court of equity and good conscience as stated in section 30(5) of the Industrial Relations Act 1967. The exercise of discretionary powers was aptly noted by John Selden, a 17th-century jurist, that: "Equity is a roguish thing: for law we have a measure; know what to trust to. Equity is according to the conscience of him that is Chancellor; and, as that is larger or narrower, so is equity. 'Tis all one, as if they should make his foot the standard for the measure we call a foot 'a Chancellor's foot'; what an uncertain measure would this be! One Chancellor has a long foot, another a short foot, a third an indifferent foot; 'tis the same thing in the Chancellor's conscience." The court will have to identify the efforts taken by the dismissed employee to mitigate his loss. If the employee had not found any new employment, the court will have to determine an appropriate cut-off point for compensation.

\section{DUTY OF DISMISSED EMPLOYEE TO MITIGATE LOSS: THE APPROACH IN UNITED KINGDOM}

The duty of a dismissed employee to mitigate loss is also the practiced in United Kingdom. For example, section 123(4) of the English Employment Rights Act, 1996 provides that in ascertaining the losses of an unfairly dismissed employee, the Tribunal shall apply the same rule concerning the duty of a person to mitigate his loss as applied to damages recoverable under the common law of England and Wales or Scotland, as the case may be. In other words, the dismissed employee must take reasonable steps to mitigate his losses for example, by answering job advertisements and registering with relevant job agency, among others. The Employment Tribunal will determine the steps taken by the employee to mitigate the loss. The tribunal must consider when it would have been reasonable for such efforts to have produced an alternative income for the employee (Savage $v$ Saxena (1998) ICR 357, EAT).

If the Tribunal finds that the claimant had failed to mitigate loss, it has the power to reduce the amount of the compensation award. The burden is on the employer to proof that the former employee failed to take reasonable steps to find another source of income and unless evidence are produced to that effect, the Employment Tribunal is under no obligation to take lost opportunities to mitigate into account against the employee. Whether the claimant had taken reasonable steps to find an alternative or new employment is a question of fact. 'The test is an objective one, based on the totality of the evidence, taking into account all relevant circumstances' (See Window Machinery Sales Ltd t/a Promac Group v Luckey UKEAT/0301/14/DA, 10 APRIL 2015).

Refusal of the employee to accept the offer of redeployment constituted an unreasonable failure to mitigate loss (See Debique v Ministry of Defence UKEAT/0075/11/SM). In Wright v Silverline Care Caledonia Ltd [2016] All ER 201, the employment tribunal decided not to make any compensatory award on the basis that the claimant had failed to mitigate his loss, having declined an offer of re-employment. The Employment Appeal Tribunal held that the applicable test is not whether an employee's conduct in refusing re-employment was reasonable, but whether the employer had shown that the employee's conduct was unreasonable. In determining whether the former employee's failure to mitigate loss by seeking alternative employment was reasonable, the Employment Appeal Tribunal in Window Machinery Sales Ltd t/a Promac Group v Luckey (2015 UKEAT 0301_14_1004), had set the guidelines to follow. In particular, Judge Richardson, delivering the judgment of the Employment Appeal Tribunal, stated:

"Where there is a substantial issue as to failure to mitigate, an Employment Tribunal may have to decide: (1) what steps it was reasonable for the Claimant to have to take in order to mitigate loss; (2) whether the Claimant did take reasonable steps to mitigate loss; and (3) to what extent, if any, the Claimant would have actually 
mitigated his loss if he had taken those steps. These questions are logically distinct, but the evidence which bears upon them will overlap and they are closely linked. The burden of proof is on the employer on all these questions. If the employer shows that there were many jobs available, it is easier for an Employment Tribunal to conclude that the employee ought to have engaged in a search for them. If the employer adduces no evidence at all on that question, it may well be difficult for an Employment Tribunal to conclude that an employee was required to engage in a substantial search for jobs.' It was further stated that 'a reasonable employee will first seek comparable employment in their own field, contacting agencies and applying for posts found. Once it becomes apparent that comparable employment is not available, a reasonable employee will generally apply for alternative forms of work, gradually considering work at a lower rate of pay and eventually considering even parttime work.'

\section{CONCLUSION}

At common law as well as under the statutory setting, the court is required to reduce or scale down the compensation for unfair dismissal when there was a post dismissal earning after the dismissal. If the court finds that the claimant had failed to mitigate loss, it has the power to reduce the amount of the compensation award. The burden is on the employer to proof that the former employee failed to take reasonable steps to find another source of income. Whether the claimant had taken reasonable steps to find an alternative or new employment is a question of fact to be determined based on the totality of the evidence, taking into account all relevant circumstances. Further, the taking into account of such employment after dismissal does not necessarily mean that the court has to conduct a mathematical exercise in deduction. The appropriate quantum of deduction is left at the discretion of the chairman to determine. However, what is apparent from the analysis of the numerous awards of the Industrial Court as discussed above is that the deduction from the claimant's backwages for the post dismissal earning is a speculative process and very much depended on the conscience of the Chairman of the Court. In other words, the chairman had used his own discretion in arriving at the deduction of only a certain percentage instead of resorting to the mathematical calculation. However, in some cases, such as in Kogilavani Muniandy and Nor Azian Bt Mohd Salleh's case, the Industrial Court had resorted to arithmetical calculation in the deduction.

\section{ACKNOWLEDGMENT}

This research was financially supported by the Research Management Centre, International Islamic University Malaysia (Grant No. EDW B14-163-1048).

\section{REFERENCE LIST}

Ashgar Ali, Ali Mohamed. (2014). Dismissal from Employment and the Remedies, (2 ${ }^{\text {nd }}$ edn.).

Ashgar Ali. Ali Mohamed. (2014). Principle of proportionality of punishment in dismissal without just cause and excuse. Industrial Law Journal, i-xviii.

Ashgar Ali, Ali Mohamed. (2005). The Remedy of Monetary Compensation in Dismissal Without Just Cause or Excuse: An Analysis. Malayan Law Journal, xxi.

C.P.Mill. (1984). Industrial Dispute Law in Malaysia (2 Edn.), 135.

J. Selden, Table Talk, quoted in M. B. Evans and R. I. Jack (eds), (1984). Sources of English Legal and Constitutional History, 223-224. 